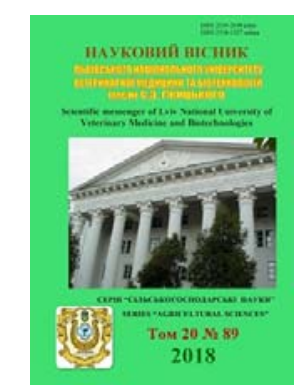

\title{
Isoenzymes spectrum of genes expression of cattle in different directions of productivity
}

\author{
V.Y. Bodnaruk, A.J. Zhmur, L.I. Muzyka, Y.G. Kropyvka, P.V. Bodnar, J.V. Poslavska, T.V. Orihivsjkyj \\ Stepan Gzhytskyi National University of Veterinary Medicine and Biotechnologies Lviv, Ukraine
}

\section{Article info}

Received 07.09.2018 Received in revised form 09.10 .2018

Accepted 10.10.2018

Stepan Gzhytskyi National University of Veterinary Medicine and Biotechnologies Lviv, Pekarska Str., 50, Lviv, 79010, Ukraine. Tel.: +38-032-239-26-82 E-mail: bodnaruk.vol@gmail.com

Bodnaruk, V.Y., Zhmur, A.J., Muzyka, L.I., Kropyvka, Y.G., Bodnar, P.V., Poslavska, J.V., \& Orihivsjkyj, T.V. (2018). Isoenzymes spectrum of genes expression of cattle in different directions of productivity. Scientific Messenger of Lviv National University of Veterinary Medicine and Biotechnologies, 20(89), 67-70. doi: 10.32718/nvlvet8912

While studying the peculiarities of the species of genetic structure of cattle, depending on the direction of productivity, one can predict, that there may be certain mechanisms that have an intermediate role between the genetically determined polymorphism of biochemical markers and the variability of complexity of the signs of productivity. One of such mechanism may be the variability of the "biochemical phenotype" of different organs - a number of organ-specific isoenzymetric spectra of genetic-biochemical systems. In this regard, in this experiment organ-specific peculiarities of the isoenzyme spectrum of various enzymes in animals of dairy and meat production were considered. For this experiment, samples of meat, and then dairy animals in pairs were placed in the electrophoretic block in the following order: lungs, heart muscle, spleen, skeletal muscle and liver. The features of the organ-specific isoenzyme spectrum of the enzymes of the general intracellular metabolism are breed and species specific. Therefore, a comparative analysis of the organ-specific spectrum of isoenzymes of various genetic-biochemical systems in these studies was performed on a small number of animals (3-5 heads). The features of the isoenzyme spectrum were evaluated by genetically-determined polymorphisms of groups of genetic-biochemical systems. Experiments were carried out on samples of homogenates of organs obtained with the addition of trilon-B. Polymorphism of enzymes was evaluated using a method of electrophoretic protein separation in 13\% starch gel in horizontal chambers with subsequent histochemical staining. These searches indicate the presence of pronounced organospecificity of the isoenzyme spectrum of purinucleoside phosphorylase, malate dehydrogenase, malic enzyme, and lactate dehydrogenase in cattle. The intraspecific differences of the organ-specific isoenzyme spectrum were revealed. It has been shown that the expression of the genetic and biochemical systems under investigation is significantly different in cattle of dairy and meat production lines in the cardiac and skeletal muscles. The "biochemical phenotype" of the heart muscle and skeletal muscle of dairy cattle is significantly different from the livestock of the meat production direction. Such studies may lead to the identification of characteristic genotypes in a complex of genetic-biochemical systems, which are closely related to the corresponding complex of economic benefits.

Key words: polymorphism, monomorphic systems, organ-specific isoenzyme spectrum, genetically determined polymorphism, biochemical markers, electrophoresis, gene expression.

\section{Ізоферментний спектр експресії генів органів великої рогатої худоби різного напрямку продуктивності}

В.Є. Боднарук, А.Й. Жмур, Л.І. Музика, Ю.Г. Кропивка, П.В. Боднар, Ю.В. Пославська, Т.В. Оріхівський

Львівський національний університет ветеринарної медицини та біотехнологій імені С.3. Гжицького, м. Львів, 79010, Украӥна

Вивчаючи породні особливості генетичної структури великої рогатої худоби в залежності від напрямку продуктивності можна передбачити, що можуть існувати певні механізми, які мають проміжну роль між генетично-детермінованим поліморфізмом біохімічних маркерів та мінливістю комплексів ознак продуктивності. Одним з таких механізмів може бути мінливість “біохімічного фенотипу” різних органів - ряду органоспецифічних ізоферментних спектрів генетико-біохімічних систем. У зв 'язку 
з ичим у даному досліді були розглянуті органоспециффічні особливості ізоферментного спектру різних ферментів у тварин молочного та м'ясного напрямку продуктивності. Для проведення даного досліду на електрофоретичному блоці попарно розміщували проби м'ясних, потім молочних тварин в такому порядку: легені, серцевий м'яз, селезінка, скелетний м'яз та печінка. Особливості органоспецифічного ізоферментного спектру ферментів загального внутрішньоклітинного метаболізму є породо- та видоспецифічними. Тому, порівняльний аналіз органоспецифічного спектру ізоферментів різних генетико-біохімічних систем в даних дослідженнях виконувався на невеликому поголів $\dddot{\imath}$ тварин (3-5 голів). Особливості ізоферментного спектру очінювали за генетичнодетермінованим поліморфізмом груп генетико-біохімічних систем. Досліди проводились на зразках гомогенатів органів одержаних з додаванням трилону-Б. Поліморфізм ферментів оцінювали, застосовуючи метод електрофоретичного розділення білків у 13\% крохмальному гелі в горизонтальних камерах з подальшим гістохімічним фарбуванням. Дані дослідження свідчать про наявність вираженої органоспецифічності ізоферментного спектру пуриннуклеозидфосфорилази, малатдегідрогенази, малик-ензиму, та лактатдегідрогенази у великої рогатої худоби. Виявлено внутрішньовидові відмінності органоспеиифічного ізоферментного спектру. Показано, шо експресія досліджуваних генетико-біохімічних систем суттєво відрізняється у великої рогатої худоби молочного та м'ясного напрямків продуктивності в серцевому та скелетному м'язах. “Біохімічний фенотип” сериевого м'яза $і$ скелетного м'яза молочної худоби істотно відрізняються від худоби м'ясного напрямку продуктивності. Такі досліджень можуть призвести до виявлення характерних генотипів за комплексом генетико-біохімічних систем, які тісно пов'язані з відповідним комплексом господарськи корисних ознак.

Ключові слова: поліморфізм, мономорфні системи, органоспецифічний ізоферментний спектр, генетично детермінований поліморфізм, біохімічні маркери, електрофорез, експресія гена.

\section{Ветуп}

Вивчення особливостей генетичної структури порід великої рогатої худоби різного напрямку продуктивності (Kopylov, 2010; Hlestkina, 2013; Dejkin et al., 2016; Bodnaruk et al., 2017; Suprovich and Mokhnachova, 2017; Bodnaruk et al., 2018), спонукало нас розглянути особливості експресії генів у різних органах (ізоферментний спектр). У питаннях вивчення особливостей генетичної диференціації різних порід худоби української селекції, поряд 3 традиційним поліморфізмом білків та ферментів все більшу роль відіграють молекулярно-генетичні методи досліджень, які можуть принципово змінити підходи до раннього прогнозування продуктивних якостей тварин (Dybus et al., 2005; Kurak et al., 2014). Найбільш інформативними в цьому аспекті є ДНК-маркерні системи, засновані на аналізі поліморфізму структурних генів, які беруть участь у формуванні та функціонуванні господарсько-корисних ознак (ці методи досліджень $\epsilon$ на сьогодні більш автоматизовані у порівнянні з білками та ферментами). До одних із найпоширеніших потенційних ДНК-маркерів ознак продуктивності великої рогатої худоби належать гени: гормону росту (bGH), бета-лактоглобуліну ( $\beta \mathrm{LG})$, тиреоглобуліну (TG5), калпаїну (CAPN), капа-казеїну (CSN3) (Suprovych and Kopylov, 2014). Ген CSN3 пов'язаний з вмістом білка в молоці та його технологічними властивостями (Suprovich and Mokhnachova, 2017). Різні алельні варіанти гена $\beta L G$ асоційовані 3 високим вмістом у молоці окремих фракцій казеїнових і сироваткових білків, відсотком жиру та позитивно впливають на молочну продуктивність (Bovenhuis et al., 1992). За цим геном здійснюється контроль якості молочних продуктів і виявлення фальсифікації молока. Доведено його роль у протимікробній активності до збудників маститу (Suprovych and Kopylov, 2014). Ген TG5 кодує попередників тиреоїдних гормонів, які беруть участь в утворенні жирових клітин i формуванні мармуровості м'яса. Ген CAPN бере участь в процесі протеолізу при дозріванні м'яса і сприяє вищій ніжності м'яса. Ген bGH є важливим регулятором соматичного росту тварин і має лактогенну та жиромобілізаційну дію (Eggena Fries, 1992; Babenko, 2015; Suprovich and Mokhnachova, 2017).

Експресія генів, як процес, при якому спадкова інформація генів (нуклеотидна послідовність) використовується для синтезу функціонального продукту (білка або РНК), активно регулюється, змінюючи час та кількість синтезованого генетичного продукту. Експресія генів забезпечує підтримання структури та функції клітини, що $є$ основою для диференціації клітин, морфогенезу, а також універсальної адаптованості будь-якого організму до умов існування.

Вивчення експресії гена в більшості проводять у крові певних видів та порід тварин так як це простіше для виконання (не потрібно вбивати тварину), але ця картина не завжди відповідає особливостям проявлення гену в різних органах. Так, наприклад, креатинкіназа, яка використовується у ветеринарії для дослідження хвороб, пов'язаних з печінкою, так як даний фермент працює в цьому циклі загального метаболізму. В крові тварини цей фермент $є$ мономорфний (проявляється тільки одна форма), тоді як у печінці великої рогатої худоби він може мати чотири ізоформи. Тому, при розгляді певної проблеми, пов'язаної $з$ печінкою, потрібно прив'язуватись до певного алелю ізоформи, а не говорити про загальну креатин-кіназу (приклади такі існують) (Taker, 1975; Zhivotovskij, 1979).

Метою наших досліджень було вивчення зв'язку між особливостями ізоферментного спектру внутрішніх органів, продуктивними якостями та міжпородною мінливістю у великої рогатої худоби.

\section{Матеріал і методи досліджень}

Порівняльну характеристику та особливості ізоферментного спектру оцінювали за генетично детермінованим поліморфізмом груп генетико-біохімічних систем. Досліди проводились на зразках гомогенатів органів, які одержували з використанням трилону-Б. Поліморфізм ферментів оцінювали, застосовуючи метод електрофоретичного розділення білків у $13 \%$ крохмальному гелі в горизонтальних мікрокамерах 3 подальшим гістохімічним фарбуванням (мікрокамери використовували для економії реактивів) (McDermid, 
1975). Дані дослідженнях виконувався на невеликому поголів'і тварин (3-5) голів. Досліджувані органи тварин були відібрані у тварин української чорнорябої молочної породи у віці 7-8 років (молочний напрямок продуктивності) та тварин волинської м'ясної породи 5-6 річного віку (м'ясний напрямок продуктивності).

\section{Результати та їх обговорення}

Вивчаючи породоспецифічні особливості генетичної структури великої рогатої худоби, можна спрогнозувати, що можуть існувати певні механізми, які мають проміжну роль між генетично - детермінованим поліморфізмом біохімічних маркерів та мінливістю комплексів ознак продуктивності. Одним 3 таких механізмів може бути мінливість “біохімічного фенотипу” різних органів - ряду органоспецифічних ізоферментних спектрів генетико-біохімічних систем. У зв’язку з цим у даному досліді були розглянуті органоспецифічні особливості ізоферментного спектру різних ферментів у тварин молочного та м'ясного напрямку продуктивності. Для проведення даного досліду на електрофоретичному блоці попарно розміщували проби м'ясних, потім молочних тварин в такому порядку: легені, серцевий м'яз, селезінка, скелетний м'яз та печінка. Порівняльний аналіз органоспецифічного спектру ізоферментів різних генетико-біохімічних систем в даних дослідження виконувався на невеликих кількостях тварин (3-5 голів).

Пуриннуклеозидфосфорилаза (NP). Даний фермент монолокусний, тетрамер. На фореграмах фермент проявляється однією зоною (фенотип NP L 3 низькою активністю), або розтягнутою плямою (висока активність NP H). Активність NP майже одинакова у більшості досліджуваних органів за виключенням спектру скелетних м'язів, де в порівнянні з іншими органами вона мінімальна. Відносна активність цих ферментів однакова у тварин молочного та м'ясного напрямків продуктивності в скелетних м'язах і відрізняється в серцевому м'язі. При проведенні міжпородного порівняння було виявлено, що в серцевому м'язі максимальна активність цього ферменту відзначається у тварин молочного напрямку продуктивності, а мінімальна активність - у тварин м'ясного напрямку продуктивності.

Слід зауважити, що за літературними даними органоспецифічна особливість експресії NP одинакова у тварин 3 генетично детермінованими відмінностями за активністю цього ферменту в еритроцитах крові (McDermid, 1975).

Лактатдегідрогеназа (LDH). Фермент тетрамер, на фореграмі було виявлено п'ять зон активності ферменту, які являють собою комбінацію субодиниць продуктів двох локусів. П'ять зон проявляються не у всіх органах. У гомогенаті легень було зафіксовано чотири зони - LDH - 1, LDH - 2, LDH - 3, LDH - 4. Найвища активність була у швидкої зони LDH -1 . При аналізі зразків серцевого м'язу проявляється переважно три зони LDH - 1, LDH - 2, LDH - 3. У селезінці також переважно три зони $\mathrm{LDH}-1, \mathrm{LDH}-2, \mathrm{LDH}-3$ та $\mathrm{LDH}$ - 4. У гомогенатах печінки було виявлено три найбільш рухливі зони. У скелетному м'язі тварини різних напрямків продуктивності проявились всі п'ять зон. Відмінність між ізоферментним спектром цих тварин була у відносній активності різних зон. Тварини м'ясного напрямку продуктивності відзначались вищою відносною активністю повільних зон LDH-5 і вона спадала до найбільш рухливих LDH-1. Тварини молочного напрямку продуктивності виділяються вищою активністю швидких зон LDH-1, LDH-2. Відмінності між тваринами молочного та м'ясного напрямку продуктивності за спектром LDH виявляються також в серцевому м'язі: у молочних тварин, на відміну від м'ясних, спостерігається експресія повільних зон LDH-4, LDH - Малатдегідрогеназа (MDH). При аналізі органоспецифічного спектру MDH на фореграмах проявилось дві зони активності ферменту: цитоплазматична та мітохондріальна, остання відзначається меншою рухливістю. Найбільша активність обох форм проявляється у серцевому м'язі. Відносно висока активність мітохондріальної форми виявлена в серцевому та скелетному м'язах і в печінці. У легенях i селезінці активність цієї зони була низька. Щодо цитоплазматичної форми, то вона представлена у всіх досліджуваних органах 3 найбільшою активністю в серцевому та скелетних мязах. У тварин молочного напрямку продуктивності активність обох форм значно вища, ніж у м'ясних в серцевому м'язі, але практично однакова в скелетних м'язах.

Малик-ензим (ME). На фореграмах виявлено дві зони активності. Цитоплазматична форма фарбується слабше та відзначається більшою рухливістю. Мітохондріальна форма характеризується вищою активністю зон.

фермент представлений п'ятьма зонами, відмінності в ізоферментному спектрі відносно активності різних зон Цитоплазматична зона проявляється у всіх пробах з максимальною активністю у печінці та серцевому м'язі і мінімально активна в легенях. Мітохондріальна зона проявляється чіткіше, але в селезінці вона відсутня. Максимальна їі активність відмічена у серцевому м'язі.

Зразки органів досліджували за слідуючими ферментами: лактатдегідрогеназа найбільша у нирках, легенях та серці -LDH-5. Разом з тим в печінці найвища активність зони LDH-1. Не у всіх органах проявляється п'ять зон. Глюкозо-6-фосфатдегідрогеназа на фореграмах виявлено дві зони. Одна зона залишається на “старті”, а друга більш рухлива. За активністю швидкої зони відзначається печінка, найменша активність цієї зони в серцевому та скелетному м'язах. Малатдегідрогеназа - майже 3 однаковою активністю проявились дві зони. Дещо вища активність швидкої зони в нирках, найменша активність повільної зони в легенях. Пуриннуклеозидфосфорилаза - проявилась одна зона, відносна активність якої найвища у легенях.

Лактатдегідрогеназа - на фореграмі проявилось п'ять зон. Переважає активність швидких зон LDH - 4 та LDH - 5.

Малатдегідрогеназа - на фореграмах проявилось дві зони. Найвищою активністю цих зон відзначалась 
велика рогата худоба молочного напрямку продуктивності, найвища активність у м'ясних тварин.

Малик-ензим - виявлено дві форми, повільна зона профарбовується чіткіше. Відносна активність окремих проб особливо не виділяється, дещо вища вона у великої рогатої худоби молочного напрямку продуктивності.

\section{Висновки}

Внаслідок виконаних досліджень одержані дані свідчать про те, що відмінності тварин за такими характеристиками молочності, як загальний надій за 305 днів першої лактації і вміст жиру в молоці супроводжується неоднаковою диференціацією їх генетичних структур за різними генетико-біохімічними системами. При різниці за надоями найбільш виражені зміни спостерігаються за локусом трансферину, а при аналізі груп тварин, що відрізняються за вмістом жиру в молоці - за локусом АМ-1. Це дозволяе припустити, що в основі таких випадків від'ємних кореляцій між даними ознаками можуть лежати специфічні міжлокусні взаємодії за різними генетико-біохімічними системами, в які і входять розглянуті нами системи. Можна говорити, що розвиток подібних досліджень може призвести до виявлення характерних генотипів за комплексом генетико-біохімічних систем, тісно пов'язаних 3 відповідним комплексом господарськи корисних ознак.

Перспективи подальших досліджень. У наступних дослідженнях буде вивчено особливості генетичної диференціації різних порід великої рогатої худоби, їх органоспецифічної експресії генів. Крім того буде проведена порівняльна оцінка близькоспоріднених видів та порід великої рогатої худоби.

\section{References}

Babenko, O.I. (2015). Zv'jazok gena somatotropnogo gormonu z gospodars'ky korysnymy oznakamy koriv ukrai'ns'koi' chorno-rjaboi' porody. Rozvedennja i genetyka tvaryn, 49, 148-153 http://digest.iabg.org.ua/genetics/item/106-49-023 (in Ukrainian).

Bodnaruk, V.Y., Bodnar, P.V., Zhmur, A.J., Muzyka, L.I., Kropyvka, Y.G., Orihivsjkyj, T.V., \& Poslavska, J.V. (2018). Options for genetic-biochemical markers in connection with dairy productivity. Scientific Messenger of Lviv National University of Veterinary Medicine and Biotechnologies, 20(84), 98-103. doi: $10.15421 /$ nvlvet8418.

Bodnaruk, V.Y., Muzyka, L.I., Bodnar, P.V., Zhmur, A.J., \& Orihivsjkyj, T.V. (2017). New possibilities of effective breeding in cattle based on the study of the genome. Scientific Messenger LNUVMB, 19(79), 32 37. doi: $10.15421 /$ nvlvet7907.

Bodnaruk,V., Shchebatyj, Z., Muzyka, L., Zhmur, A., \& Orikhivskyj, T. (2017). Genofond of some breed of cattle. Scientific Messenger LNUVMBT named after S.Z. Gzhytskyj, 19 (74), 131-134. doi: $10.15421 /$ nvlvet7429.
Bovenhuis, H., Van Arendonk, J.A.M., \& Korver, S. (1992). Associations Between Milk Protein Polymorphisms and Milk Production Traits. J. Dairy Sci., 75, 2549-2559. doi: 10.3168/jds.S00220302(92)78017-5.

Dejkin, A.V., Selionova, M.I., Krivoruchko, A.Ju., Kovalenko, D.V., Truhachev, V.I. (2016). Geneticheskie markery v mjasnom ovcevodstve. Vavilovskij zhurnal genetiki i selekcii, 20(5), 576583. doi: 10.18699/VJ16.139.

Dybus, A., Grzesiak, W., Kamieniecki, H., Szatkowska, I., Sobek, Z., Blaszczyk, P., Czerniawska-Piatkowska, E., Zych, S., \& Muszynska, M. (2005). Association of genetic variants of bovine prolactin with milk production traits of Black-and-White and Jersey cattle. Archiv Tierzucht, 48(2), 149-156. doi: 10.5194/aab48-149-2005.

Eggena Fries, R. (1992). Die Untersuchung von Kaseingenenmittels DNA-Analyse. ETH Landwirtschaft Schweb Band, 231-235.

Hlestkina, E.K. (2013). Molekuljarnye markery v geneticheskih issledovanijah i v selekcii. Vavilovskij zhurnal genetiki i selekcii, 17(4/2), 1044-1054 (in Russian).

Kopylov, K.V. (2010). Genetychna struktura riznyh porid velykoi' rogatoi' hudoby za lokusamy kil'kisnyh oznak. Rozvedennja i genetyka tvaryn, 44, 91-95 (in Ukrainian).

Kurak, O.P., Gandzha, A.Y., Zhuryna, N.V., Letkevych, L.L., Symonenko, V.P., Koval'chuk, M.A., \& Kyryllova, Y.V. (2014). Monytoryng krupnogo rogatogo skota belorusskoj cherno-pestroj porodы ро lokusam hozjajstvenno-znachymыh pryznakov. Rozvedennja i genetyka tvaryn. 48, 194-202. http://digest.iabg.org.ua/genetics/item/62-48-027 (in Ukrainian).

McDermid, E.M., Agar, N.S., \& Chai, C.K. (1975). Electrophoretic variation of red cell enzyme sustems in farm animals. Anim. Blood Groups and Biochem. Genet., 6 (3), 127-174. https://www.ncbi.nlm.nih.gov/ pubmed/812391.

Suprovich, T., \& Mokhnachova, N. (2017). Gene polymorphism of economically-useful traits in ukrainian gray cattle breed. The Animal Biology, 19 (1), 111118. doi: 10.15407/animbiol19.01.111.

Suprovych, T.M., \& Kopylov, K.V. (2014). Vyznachennja DNK-markeriv u shyl'nyh ta rezystentnyh do mastytiv koriv ukrai'ns'koi' chornorjaboi' molochnoi' porody. Rozvedennja i genetyka tvaryn, 48, 214-223. http://digest.iabg.org.ua/genetics/ item/66-48-030 (in Ukrainian).

Taker, E. (1975). Genetic differences in metabolism of farm animals. The Blood of Sheep. Berlin: Springer - verlog, 123-151. https://www.ncbi.nlm.nih.gov/pubmed/ 331333.

Zhivotovskij, L.A. (1979). Pokazatel' shodstva populjacij po polimorfnym priznakam. Zhurn. obshhej biologii. 40(4), 587-602 (in Russian). 